\title{
Hegemonia e a reconstrução ética no pensamento de Antonio Gramsci
}

\section{Mestranda em Serviço Social pela Universidade Federal de Pernambuco \\ Eveline de Sousa Landim \\ Graduanda da Universidade Estadual do Ceará}

\section{Resumo}

O trabalho consiste no estudo da relação entre o conceito de hegemonia na obra do pensador e militante italiano Antônio Gramsci e a construção de uma nova moralidade a partir da reflexão e vivência de valores emancipatórios. Tal relação se fundamenta na medida em que observamos a conceituação gramsciana acerca do processo de conquista de hegemonia que pode ser primordialmente compreendido como reforma intelectual e moral, ou seja, um espraiamento de uma determinada concepção de mundo e divulgação das conquistas culturais para amplas camadas da população bem como a vivência de valores e a construção de uma nova moral a partir da reflexão ética.

Palavras-chave: Hegemonia; Cultura; Ética.

\section{Resumen}

El trabajo consiste en el estudio de la relación entre el concepto de hegemonia en la obra del pensador y militante italiano Antônio Gramsci y la construcción de una nueva moralidade a partir de la reflexión y vivencia de valores emancipatórios. Tal relación se fundamenta la medida en que observamos a conceituação gramsciana acerca del proceso de conquista de hegemonia que puede ser primordialmente comprendido como reforma intelectual y moral, o sea, un espraiamento de una determinada concepción de mundo y divulgación de las conquistas culturales para amplias capas de la población así como la vivencia de valores y la construcción de una nueva moral a partir de la reflexión ética.

Palabras clave: Hegemonía; Cultura; Ética. 
$\mathrm{E}$

sta pesquisa pretende abordar temas como ética, cultura e sua relação com o conceito de hegemonia tão fecundo na obra do pensador sardo Antônio Gramsci.

O estudo aqui realizado consiste na análise da referida categoria gramsciana que em linhas gerais pode ser compreendida como conquista da direção política, cultural e econômica da sociedade, por meio da disseminação de uma determinada concepção de mundo que põe em crise a ideologia hegemônica.

Hegemonia, portanto, pode ser considerada como uma reforma intelectual e moral, uma concepção que conquista novos aderentes. É obra política, organizativa, pedagógica de difusão de novas conquistas culturais, diferenciando-se assim, da conquista do poder primeiramente pela força, mas atuando principalmente através do consenso no qual diferentes setores se unificam em torno de um mesmo projeto.

Ao compreender a conquista da hegemonia centralmente como reforma intelectual e moral podemos dessa forma visualizar uma relação entre a construção da hegemonia e o desenvolvimento de uma nova moral a partir da reflexão ética.

Imbuídas do desejo de compreender a articulação entre moral, cultura e hegemonia, tendo como premissa de que esta última propõe uma ligação estreita com a construção de novos valores, com a recriação ética do sujeito, nos debruçamos, portanto, sobre a obra gramsciana. Lançamos o olhar sobre a reconstrução da moral enquanto reflexão da ética, e de que forma isso se relaciona com a conceituação de hegemonia para Gramsci.

Dessa forma, nosso trabalho observa a contribuição gramsciana para o entendimento da subjetividade humana, no campo da construção de novos valores e de novas relações, enfim, de uma nova cultura que deve ser compreendida como concepção de mundo e forma de vida que, por sua vez, para o pensador, está dialeticamente conectada com a transformação radical das formas econômicas de produção, com a política revolucionária, com a construção de uma nova sociedade.

Para tal estudo, realizamos análise bibliográfica dos escritos 
carcerários de Gramsci nos quais o pensador se refere à questão da hegemonia e revisitamos autores que se debruçam de forma mais fiel ao pensamento político e filosófico do pensador sardo.

Outrossim, para estudo e análise do conceito de hegemonia em Gramsci e sua relação com a construção de uma nova moral, analisamos autores que trabalham a problemática da moral e da ética. 